\title{
Analisa Gula Kristal Putih Secara Cepat Menggunakan Near Infrared Spectroscopy
}

\author{
Rapid Analysis of Plantation White Sugar \\ Using Near Infrared Spectroscopy
}

\author{
Opal Priya Wening ${ }^{1)}$ \\ 1) Pusat Penelitian Perkebunan Gula Indonesia, Pasuruan \\ Alamat korespondensi, Email: opalpriyawening@gmail.com
}

\begin{abstract}
ABSTRAK
Near infrared spectroscopy (NIRS) merupakan metode alternatif untuk menganalisa parameter sampel yang lebih cepat. Pada penelitian ini, NIRS digunakan sebagai penentuan kualitas gula kristal putih (GKP) dengan parameter penting seperti pol, warna, susut pengeringan, dan besar jenis butiran. Sampel gula yang digunakan berasal dari laboratorium P3GI. Instrumen NIRS menggunakan FOSS XDS rapid content analysis, kemudian model yang dibangun menggunakan metode kalibrasi partial least square (PLS). Penelitian ini menggunakan metode cross-validation antara sampel kalibrasi dengan validasi. Hasil NIRS dievaluasi dengan standar yang telah ditetapkan: nilai korelasi coefficient of determination of calibration $\left(\mathrm{R}^{2}\right)$ dan coefficient of determination for cross-validation $\left(\mathrm{r}^{2}\right)$ yang mendekati 1 , standard error of calibration (SEC) yang rendah, dan ratio of prediction to deviation (RPD) yang tinggi. Penelitian menghasilkan nilai hasil analisis tertentu untuk pol $(\%)$ : $\mathrm{R}^{2}=0,970$, SEC $=0,023, r^{2}=0,496, \mathrm{RPD}=1,152$; warna $(\mathrm{IU}): \mathrm{R}^{2}=0,970, \mathrm{SEC}=12,305, \mathrm{r}^{2}=0,757$, $\mathrm{RPD}=1,529$; susut pengeringan $(\%): \mathrm{R}^{2}=0,973, \mathrm{SEC}=0,004, \mathrm{r}^{2}=0,789, \mathrm{RPD}=1,601$; dan besar jenis butiran (mm): $\mathrm{R}^{2}=0,954, \mathrm{SEC}=0,038, \mathrm{r}^{2}=0,407, \mathrm{RPD}=0,997$. Berdasarkan hasil evaluasi tersebut metode NIRS berpotensi sebagai analisa kualitas gula kristal putih dengan model yang dibangun tergolong sebagai pendahuluan.
\end{abstract}

Kata kunci: NIRS, gula kristal putih, analisa kualitas gula

\begin{abstract}
Near infrared spectroscopy (NIRS) is an alternative method for faster analysis sample parameter. In this study, NIRS was used to determine the quality of plantation white sugar with important parameters, such as pol (\%), color (IU), moisture (\%), and granular (mm). Plantation white sugar samples were obtained from ISRI's Laboratory. NIRS instrument used was FOSS XRD rapid content analysis, then the model was built using partial least square (PLS) calibration method. This study used cross-validation between calibration and validation samples. NIRS results were evaluated by certain standard: coefficient of determination of calibration $\left(R^{2}\right)$ or coefficient of determination for cross-validation $\left(r^{2}\right)$ correlation which is close to 1, low calibration of standard error of calibration (SEC), and high ratio of ratio of prediction to deviation $(R P D)$. The results showed different values for each parameter for pol $(\%): R^{2}=0,970, S E C=0,023, r^{2}=0,496, R P D=1,152$; for color
\end{abstract}


$(I U): R^{2}=0,970, S E C=12,305, r^{2}=0,757, R P D=1,529 ;$ for moisture $(\%): R^{2}=0,973$, $S E C=0,004, r^{2}=0,789, R P D=1,601$; for granular $(\mathrm{mm}): R^{2}=0,954, S E C=0,038, r^{2}=$ 0,407, RPD =0,997. Based on the evaluation NIRS method showed a potential method for plantation white sugar quality analysis with model is classified as an introduction.

Key words: NIRS, plantation white sugar, sugar quality analysis

\section{PENDAHULUAN}

Penentuan kualitas gula kristal putih (GKP) sesuai dengan SNI dapat dilakukan melalui analisa beberapa parameter penting di laboratorium. Nilai yang dihasilkan dari setiap parameter selain dapat menentukan kualitas juga dapat digunakan sebagai kesesuaian standar dan penerimaan konsumen terhadap GKP. Secara signifikan, nilai dari parameter tersebut dapat memeberikan informasi bagaimana proses yang terjadi di pabrik gula, mulai dari kondisi bahan input sampai dengan proses pengolahan. Analisa GKP yang dilakukan di pabrik gula selama ini menggunakan metode konvensional (kimia) di laboratorium yang mengacu pada metode SNI 3140.3: 2020 (Badan Standarisasi Nasional, 2020). Namun, terdapat beberapa kelemahan dari metode ini seperti membutuhkan dan menghabiskan banyak waktu, tenaga, dan biaya serta kemampuan jumlah sampel yang dapat dianalisa sangat terbatas, sehingga dibutuhkan metode alternatif yang lebih cepat, efisien, dan handal dalam melakukan analisa GKP.

Near infrared spectorscopy (NIRS) merupakan metode handal untuk analisis berbagai parameter yang dikehendaki. Berbagai sektor industri seperti petrokimia (Larrechi \& Callao, 2003), minuman (Rodriguez-Saona et al., 2001), susu (Cattaneo \& Holroyd, 2013), makanan (Dodds \& Heath, 2005), farmasi (Carlsson \& Janné, 1995) serta pakan (Samadi et al., 2018) telah mengembangkan dan mengaplikasikan instrumen NIRS. Keunggulan analisis menggunakan NIRS secara rutin dibandingkan dengan analisis konvensional (kimia) adalah biaya yang rendah (tenaga kerja dan utilitas atau bahan kimia), kecepatan serta kemudahan analisis karena persiapan sampel tanpa merusak (nondestructive) (Day \& Fearn, 1982; Blanco \& Villarroya, 2002; Pasquini, 2003; O'Shea et al., 2011). Keunggulan lainnya yaitu dapat mengurangi risiko analis dari bahan berbahaya, memperkecil kesulitan prosedural yang bersifat teknis, mencegah kesalahan penginputan data, serta tidak membutuhkan analis dengan keterampilan teknis dan kompeten (O'Shea, 2011).

Industri gula dunia telah banyak mengembangkan dan mengaplikasikan metode analisa NIRS. Pada produk GKP, NIRS dapat digunakan sebagai analisa parameter penting, seperti pada produk raw sugar untuk mengetahui brix, warna (ICUMSA), gula reduksi, abu, dan kadar air (Bevin et al., 2002). Brotherton \& Berding (1995) telah membuktikan bahwa pengukuran pol dan kadar air menggunakan NIRS dapat memberikan hasil yang memuaskan. NIRS juga dapat digunakan secara online untuk menganalisis produk gula atau disebut sugar analysis systems (SAS), sehingga data yang didapatkan kemudian dapat digunakan untuk berbagai macam aplikasi (Staunton et al., 1999; Bevin et al., 2002; Staunton \& Wardrop, 2006). Di Indonesia, industri gula sudah menggunakan NIRS untuk pengukuran kualitas tebu yang diaplikasikan pada core sampler (Kuswurjanto \& Triantarti, 2019; Kuswurjanto et al., 2019). Keberhasilan tersebut digunakan sebagai dasar untuk mengeksplorasi potensi NIRS lebih lanjut untuk analisis berbagai sampel berbeda yang 
ada di pabrik gula, yaitu GKP. Tujuan penelitian akan berfokus pada penggunaan metode NIRS dan instrumennya untuk mempelajari potensinya menganalisis parameter penting GKP yaitu pol (\%), warna (IU), susut pengeringan (\%), dan besar jenis butiran (mm).

\section{METODE}

\section{Waktu dan Tempat}

Koleksi data pada penelitian ini dilakukan selama 2 bulan, yaitu bulan Januari - Febuari tahun 2021 bertempat di Laboratorium Jasa Pusat Penelitian Perkebunan Gula Indonesia, Pasuruan (P3GI).

\section{Bahan dan Alat}

Bahan utama yang digunakan merupakan sampel GKP yang diperoleh dari P3GI. Sampel tersebut berasal dari berbagai pabrik gula yang diambil acak secara periodik. Bahan pembantu yang digunakan merupakan bahan set kimia untuk analisis pol, warna, susut pengeringan, dan besar jenis butiran. Alat yang digunakan untuk analisa konvensional (kimia) adalah perlengkapan set analisis laboratorium seperti labu takar, pipet, neraca analitik, erlenmeyer, pompa vakum, syringes, spektrofotometer, kuvet, ultrasonic bath, refraktometer dan lain-lain. Alat yang digunakan untuk analisa NIRS dengan pengambilan dan pengolahan data spektrum adalah instrumen NIRS FOSS XDS Rapid Content Analyzer mode pantulan (reflectance mode) yang telah tehubung dengan satu perangkat komputer, UPS Power, dan terinstal Visio Software (Windows Infrasoft International Version 4.10.0.15326) sebagai pemrosesan data dan analisis statistik.

\section{Metode Analisa Konvensional}

Pengukuran parameter pol, warna, susut pengeringan, dan besar jenis butiran menggunakan metode konvensional yang mengacu pada SNI 3140.3: 2020 (Badan Standarisasi Nasional, 2020).

\section{Metode Analisa NIRS}

Pengukuran dan pemindahan (scan) sampel GKP menggunakan instrumen NIRS FOSS XDS Rapid Content Analyzer pada rentang panjang gelombang $400-2.500 \mathrm{~nm}$ (Gambar 1). Sampel diletakkan pada sample cell (solid) sebanyak \pm 100 gram, kemudian dilakukan proses pemindahan (scan) dan analisa statistik dengan menggunakan Vision Software. Pengolahan data spektrum NIR dilakukan menggunakan visio software (windows infrasoft international, versi 4.10.0.15326) kemometrik package. Sampel kemudian dibedakan menjadi dua kelompok, yaitu kalibrasi dan validasi. Sampel diolah menggunakan visio software dan model dikembangkan menggunakan metode silang (cross-method) antara sampel kalibrasi dengan validasi sebagai uji kasus dan teknik untuk validitas. Model dibangun dengan menggunakan metode statistik: partial least square (PLS), yaitu menggunakan full spectra dan rentang spektrum sebagai informasi (Donald et al., 2013).

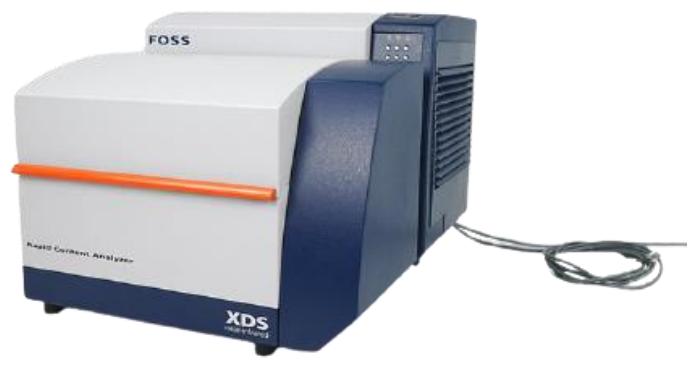

Gambar 1. Instumen NIRS FOSS XDS rapid content analyzer

Figure 1. NIRS FOSS XDS rapid content analyzer instrument

Penentuan performa model dapat dievaluasi dengan membandingkan model hasil persamaan dan statistik dari kalibrasi kedua metode (konvensional \& NIRS) yang 
sudah dilakukan validasi dan menghasilkan koofisien korelasi. Parameter statisitk yang dapat dievaluasi yaitu: coefficient of determination of calibration $\left(\mathrm{R}^{2}\right)$, standard error of calibration (SEC), standard error of cross-validation (SECV), coefficient of determination for cross-validation $\left(\mathrm{r}^{2}\right)$, standard error prediction (SEP), dan ratio of prediction to deviation (RPD) (Rinnan et al., 2009). $R^{2}$ atau $r^{2}$ menyatakan berapa banyak variasi dan informasi yang dijelaskan dan kecocokannya dalam suatu model. SEC menunjukkan seberapa baik kecocokan persamaan kalibrasi dengan data, apabila nilainya semakin kecil menunjukkan kesalahan prediksi yang rendah dari kalibrasi. SECV menunjukkan error sebanding dengan rata-rata data kimia sampel. SEP menunjukkan ketidaktepatan (kualitas) dari model validasi, nilai yang kecil menunjukkan bahwa model yang dibangun adalah baik. RPD menunjukkan rasio antara standar deviasi dari data original referensi dengan SEC dan SEP. Model dapat dikatakan baik apabila memiliki nilai $\mathrm{R}^{2}$ atau $\mathrm{r}^{2}$ mendekati 1,0 (tinggi); error (SEC, SECV \& SEP) mendekati 0 atau < SD (rendah); serta RPD > 2,0 (tinggi). Nilai RPD yang berada pada rentang 2,00 - 3,00 menunjukkan metode dapat digunakan untuk pendekatan prediksi kuantitatif dan termasuk good model performance (Nicolaï et al., 2007; Lebot et al., 2009)

\section{HASIL DAN PEMBAHASAN}

\section{Data Set untuk Kalibrasi dan Validasi}

Sampel GKP yang digunakan sebagai data set kalibrasi NIRS sebanyak 40 sampel dan validasi sebanyak 10 sampel. Sebaran data hasil pengukuran dan perhitungan statistik dari karakteristik sampel GKP tersebut disampaikan pada Tabel 1. Sebaran jenis data kalibrasi dan validasi untuk rataan pada seluruh parameter (pol, warna, susut pengeringan, dan besar jenis butiran) hampir identik sehingga dapat dikatakan penyusunan data sudah baik. Keseluruhan sampel GKP yang digunakan berasal dari berbagai pabrik gula setiap periode (satu periode $=15$ hari) selama satu musim giling sehingga sampel yang digunakan dapat dianggap mewakili. Namun pada nilai standar deviasi (SD) kedua jenis datanya bervariasi. Parameter pol, susut pengeringan, dan besar jenis butiran memiliki nilai SD yang sangat rendah $(<0,15)$, sedangkan parameter warna nilai memmiliki SD yang sangat tinggi (> 40,00). Apabila SD bernilai sangat rendah, maka akan menjadi salah satu kelemahan metode spektroskopi NIRS. Namun apabila semakin tinggi nilai SD maka akan terjadi keberagaman sumber data dan sangat sesuai untuk membangun model kalibrasi NIRS, sebaliknya semakin rendah nilainya maka sumber data semakin homogen.

\section{Hasil Statistik Kalibrasi dan Prediksi}

Hasil pengolahan statistik dan performa sampel GKP dapat dilihat pada Tabel 2 . Model kalibrasi terbaik yang didapatkan dengan menggunakan faktor PLS $=9$. Nilai $\mathrm{R}^{2}$ kalibrasi pada seluruh parameter secara berurutan sangat baik dan tinggi dengan nilai 0,970; 0,970; 0,973; dan 0,954. Plot data kalibrasi dapat dilhat pada Gambar 2. Hasil tersebut sudah sesuai dengan syarat kebertenerimaan kalibrasi pada nilai $\mathrm{R}^{2} \geq$ 0,95 (Kuswurjanto \& Triantarti, 2019). Berbeda dengan $r^{2}$ yang masih bernilai $<0,85$ sehingga model yang didapatkan untuk memprediksi masih belum akurat. Nilai error SEC \& SECV pada parameter pol, warna, dan besar jenis butiran sangat rendah $(0,004-$ 0,$038 ; 0,017-0,203$; mendekati 0). Hal ini menunjukkan bahwa kedua metode menghasilkan nilai yang hampir mendekati atau dikatakan sudah baik. Namun berbeda dengan parameter warna yang memilik nilai error yang tinggi $(12,305 ; 63,178)$. Beberapa 
hasil penelitian juga memiliki nilai error yang tinggi, seperti pada sampel raw sugar: O'Shea et al., (2011) dengan nilai SEC \& SECV pada instrumen FOSS InfraXact $=$ 104,0; 117,0 dan Bruker MPA = 120,0; 147,0. Nilai error yang tinggi disebabkan oleh nilai bias antara nilai hasil analisis spektrum NIRS prediksi dengan nilai sebenarnya (konvensional) sangat tinggi. Williams (1987) menyatakan bahwa nilai bias akan berkolerasi linier terhadap nilai standard error.

Tabel 1. Karakteristik sampel GKP

Tabel 1. Characteristic of GKP sample

\begin{tabular}{|c|c|c|c|c|c|}
\hline Parameter & Jenis data & Rataan & Min. & Maks. & Std. deviasi (SD) \\
\hline Parameter & Data type & Mean & Min. & $\operatorname{Max}$. & Deviation Std. (DS) \\
\hline Pol, \% & Kalibrasi & 99,74 & 99,45 & 99,90 & 0,11 \\
\hline Pol, (\%) & Validasi & 99,72 & 99,50 & 99,82 & 0,09 \\
\hline Warna, IU & Kalibrasi & 201,73 & 99,00 & 315,00 & 59,09 \\
\hline Color, IU & Validasi & 213,30 & 122,00 & 280,00 & 48,25 \\
\hline Susut Pengeringan, $\%$ & Kalibrasi & 0,03 & 0,01 & 0,08 & 0,02 \\
\hline Moisture, \% & Validasi & 0,03 & 0,02 & 0,04 & 0,01 \\
\hline Besar Jenis Butir, mm & Kalibrasi & 1,03 & 0,65 & 1,28 & 0,14 \\
\hline Granular, $m m$ & Validasi & 1,05 & 0,84 & 1,28 & 0,14 \\
\hline
\end{tabular}

Tabel 2. Performa statistik pada kalibrasi dan prediksi GKP dari kedua metode

Tabel 2. Statistical performance on plantation white sugar calibration and prediction of both methods

\begin{tabular}{|c|c|c|c|c|c|c|c|c|c|}
\hline \multirow{2}{*}{$\begin{array}{l}\text { Parameter } \\
\text { Parameter }\end{array}$} & \multirow[t]{2}{*}{ PLS } & \multicolumn{4}{|c|}{$\begin{array}{l}\text { Kalibrasi } \\
\text { Calibration }\end{array}$} & \multicolumn{4}{|c|}{$\begin{array}{l}\text { Prediksi } \\
\text { Prediction }\end{array}$} \\
\hline & & $\mathrm{N}$ & $\mathrm{R}^{2}$ & SEC & SECV & $\mathrm{N}$ & $r^{2}$ & SEP & RPD \\
\hline Pol, \% & 9 & 40 & 0,970 & 0,023 & 0,116 & 10 & 0,496 & 0,075 & 1,152 \\
\hline Pol, \% & & & & & & & & & \\
\hline Warna, IU & 9 & 40 & 0,970 & 12,305 & 63,178 & 10 & 0,757 & 31,547 & 1,529 \\
\hline Color, IU & & & & & & & & & \\
\hline $\begin{array}{l}\text { Susut Pengeringan, \% } \\
\text { Moisture, \% }\end{array}$ & 9 & 40 & 0,973 & 0,004 & 0,017 & 10 & 0,789 & 0,004 & 1,601 \\
\hline $\begin{array}{l}\text { Besar Jenis Butiran, mm } \\
\text { Granular, } \mathrm{mm}\end{array}$ & 9 & 40 & 0,954 & 0,038 & 0,203 & 10 & 0,407 & 0,146 & 0,997 \\
\hline
\end{tabular}

Keterangan: $\mathrm{N}=$ jumlah sampel $; \mathrm{SEC}=$ standard error calibration; $\mathrm{SECV}=$ standard error cross validation; $\mathrm{SEP}=$ standard error prediction $; \mathrm{RPD}=$ ratio of prediction to deviation $(\mathrm{SD} / \mathrm{SEP})$

Note: $N=$ sample number SEC = standard error calibration; SECV = standard error cross validation; SEP = standard error prediction; $R P D=$ ratio of prediction to deviation $(S D / S E P)$ 
Calibration Set : Calculated vs Lab Data

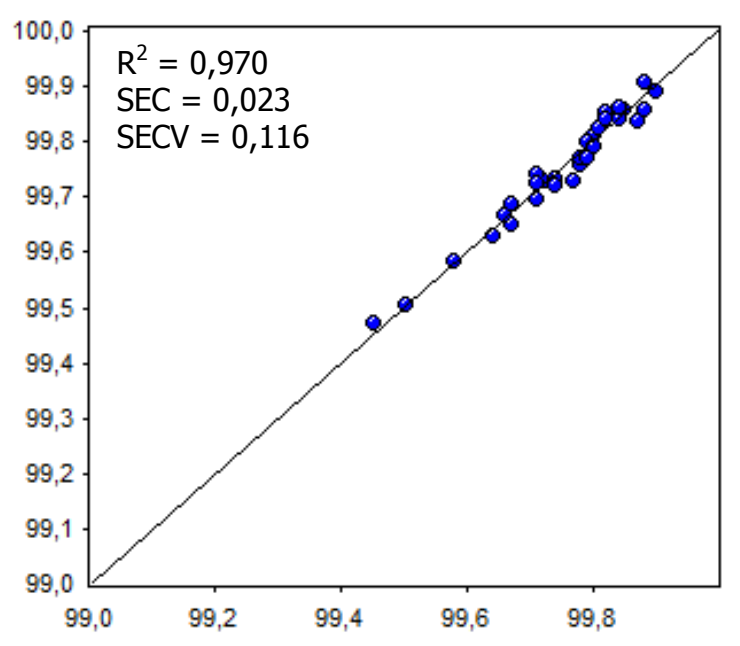

(a) Hasil pengukuran pol $(\%)$

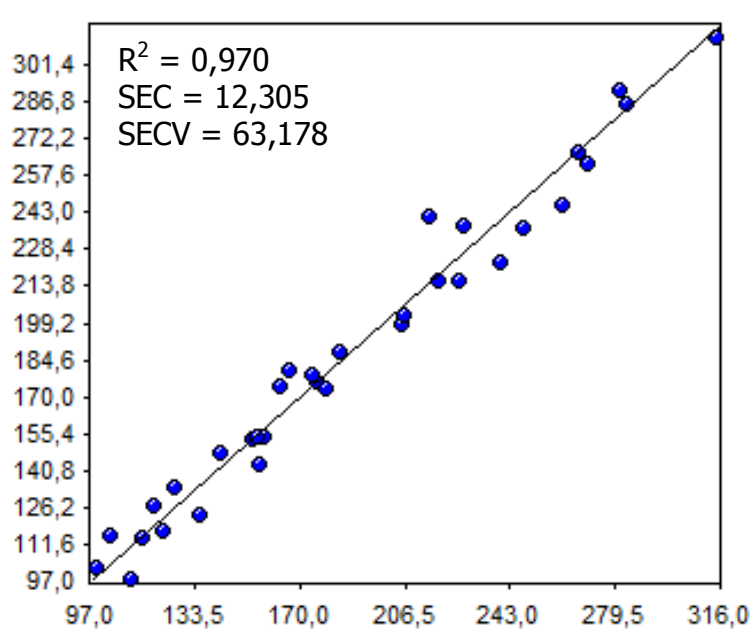

(b) Hasil pengukuran warna (IU)

Calibration Set : Calculated vs Lab Data

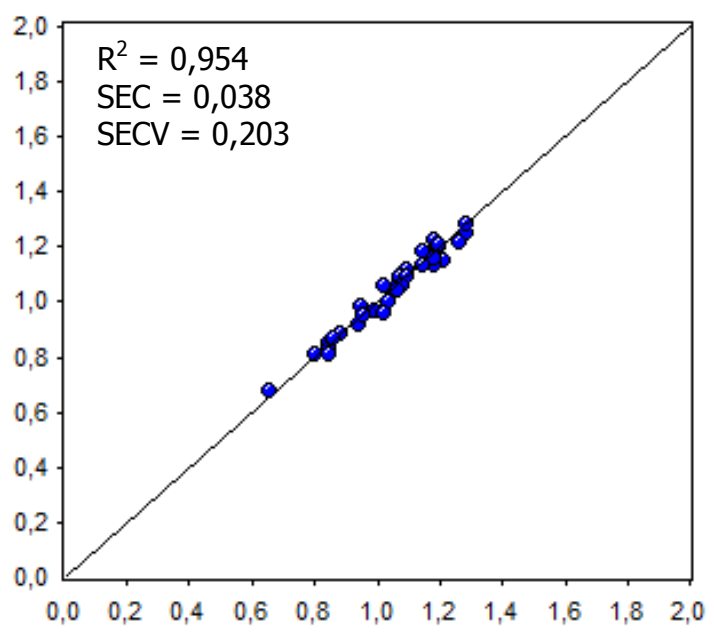

(d) Hasil pengukuran besar jenis butiran $(\mathrm{mm})$

Gambar 2. Plot kalibrasi beberapa parameter analisa dari metode konvensional (x) dengan NIR Spectoscopy (y) menggunakan sampel GKP

Figure 2. Plot calibration of several analytical parameters from conventional method $(x)$ with NIR Spectroscopy (y) using plantation white sugar samples

Proses menguji ketepatan model yang dihasilkan menggunakan sampel validasi. Nilai SEP untuk pramater pol, susut pengeringan, dan besar jenis butiran $(0,075$;
0,004; 0,146) mendekati nol atau termasuk sangat rendah. Namun pada parameter warna, memiliki nilai yang tinggi $(31,547)$. Penelitian Bevin et al., (2002) pada sampel 
raw sugar juga memiliki nilai SEP yang tinggi $=160,6 ; 219,7 ; 236,5 ; 148,6 ; 97,1$. Teknik untuk memperkuat nilai SEC, SECV dan SEP supaya didapatkan nilai yang lebih rendah dapat dilakukan dengan memperbanyak sampel GKP kalibrasi dari berbagai musim giling (Bevin et al., 2002). Nilai RPD yang dihasilkan seluruh parameter diantara $0,997-1,601$ sehingga tergolong cukup rendah dan dikatakan bahwa model yang dibangun belum dapat memenuhi standar $(>2,00)$ sehingga tidak dapat memprediksi sampel GKP.

\section{KESIMPULAN}

Hasil penelitian ini menunjukkan penggunaan NIRS berpotensi sebagai metode alternatif untuk menganalisis kualitas GKP, seperti parameter pol (\%), warna (IU), susut bobot (\%), dan besar jenis butir $(\mathrm{mm})$. Nilai $\mathrm{R}^{2}$ dari keseluruhan parameter sudah sesuai standar, sedangkan untuk $\mathrm{r}^{2}$ nilainya masih terlalu jauh dari standar. Nilai error (SEC, SECV, dan SEP) pada parameter warna masih tinggi, sedangkan parameter lainnya sudah memiliki nilai rendah. RPD dari keseluruhan parameter bernilai rendah, sehingga model prediksi yang dibangun tergolong kasar, hanya bisa digolongkan sebagai pendahuluan. Perbaikan nilai error dapat dilakukan dengan melakukan koleksi data kalibrasi-validasi yang lebih banyak dari sampel GKP mulai awal hingga akhir musim giling dan beberapa musim giling untuk memperkaya serta menghasilkan model yang lebih baik dan akurat.

\section{DAFTAR PUSTAKA}

Badan Standarisasi Nasional. (2020). Standar Nasional Indonesia 3140.3:2020 Gula Kristal Putih (Plantation White Sugar) Gula kristal -
Putih. Bagian $3: 1-17$.

Bevin, C., Staunton, S., Stobie, R., \& Kingston, J. (2002). On-line use of near infrared spectroscopy in a sugar analysis system (SAS). 24.

Blanco, M., \& Villarroya, I. (2002). NIR spectroscopy: a rapid-response analytical tool. TrAC - Trends in Analytical Chemistry, 21(4), 240-250.

Brotherton, G., \& Berding, N. (1995). Near infra-red spectroscopic applications for milling: prospects and implications. Proc Aust Soc Sugar Cane Technol, 13, 21-29.

Carlsson, A. E., \& Janné, K. L.-R. (1995). Near-infrared spectroscopy as an alternative to biological testing for quality control of hyaluronan: comparison of data preprocessing methods for classification. Applied Spectroscopy, 49(7), 1037-1040.

Cattaneo, T. M. P., \& Holroyd, S. E. (2013). New applications of near infrared spectroscopy on dairy products. Journal of Near Infrared Spectroscopy, 21(5), 307-310. https://doi.org/10.1255/jnirs.1078

Day, M., \& Fearn, F. (1982). Near infrared reflectance as an analytical technique part 1: history and development. Laboratory Practice, 31, 328-330.

Dodds, S. A., \& Heath, W. P. (2005). Construction of an online reducedspectrum NIR calibration model from full-spectrum data. Chemometrics and Intelligent Laboratory Systems, 76(1), 37-43.

Donald, D. A., Graham, B. E. N. G., Staunton, S. P., Simpson, J. M., \& Shea, M. G. O. (2013). Routine data generation for sugar mill and refinery applications using a laboratory-based near infrared (NIR) instrument. 35, 19.

Kuswurjanto, R., \& Triantarti. (2019). Study on application of near infrared (NIR) spectroscopy for sugar cane juice analysis to replace conventional 
analysis methods. IOP Conference Series: Earth and Environmental Science, 355(1).

Kuswurjanto, R., Triantarti, \& Wening, O. (2019). Application of near infrared spectroscopy to determine sugarcane quality in core sampler system. The Second International Conference on Food and Agriculture, 399-406.

Larrechi, M. S., \& Callao, M. P. (2003). Strategy for introducing NIR spectroscopy and multivariate calibration techniques in industry. TrAC - Trends in Analytical Chemistry, 22(9), 634-640.

Lebot, V., Champagne, A., Malapa, R., \& Shiley, D. (2009). NIR determination of major constituents in tropical root and tuber crop flours. Journal of Agricultural and Food Chemistry, 57(22), 10539-10547.

Nicolaï, B. M., Beullens, K., Bobelyn, E., Peirs, A., Saeys, W., Theron, K. I., \& Lammertyn, J. (2007). Nondestructive measurement of fruit and vegetable quality by means of NIR spectroscopy: A review. Postharvest Biology and Technology, 46(2), 99-118.

O'Shea, M. G., Staunton, S. P., Donald, D., \& Simpson, J. (2011). Developing laboratory near infra-red (NIR) instruments for the analysis of sugar factory products. 33rd Annual Conference of the Australian Society of Sugar Cane Technologists 2011, ASSCT 2011, 33, 278-285.

Pasquini, C. (2003). Near infrared spectroscopy: fundamentals, practical aspects and analytical applications. Journal of the Brazilian Chemical Society, 14(2), 198-219.
Rinnan, Å., Berg, F. van den, \& Engelsen, S. B. (2009). Review of the most common pre-processing techniques for near-infrared spectra. TrAC - Trends in Analytical Chemistry, 28(10), 12011222.

Rodriguez-Saona, L. E., Khambaty, F. M., Fry, F. S., \& Calvey, E. M. (2001). Rapid detection and identification of bacterial strains by fourier transform near-infrared spectroscopy. Journal of Agricultural and Food Chemistry, 49(2), 574-579.

Samadi, Wajizah, S., \& Munawar, A. A. (2018). Rapid and simultaneous determination of feed nutritive values by means of near infrared spectroscopy. Tropical Animal Science Journal, 41(2), 121-127.

Staunton, S., Lethbridge, P., Grimley, S., Streamer, R., Rogers, J., \& Mackintosh, D. (1999). On-line analysis cane analysis by near infra-red spectroscopy. Proceedings of The Australian Society of Sugar Cane Technologists, 21, 20-27.

Staunton, S., \& Wardrop, K. (2006). Development of an online bagasse analysis system using NIR spectroscopy. Proceedings of The Australian Society of Sugar Cane Technologists, 28, 446-453.

Williams, P. (1987). Variables affecting near-infrared reflectance spectroscopic analysis. In P. Williams and K. Norris (eds.). Near-Infrared Technology in the Agricultural and Food Industries. St. Paul, MN: American Association of Cereal Chemists Inc, 143-167. 